\title{
The Rheumatoid Hand Seen by the Hand Surgeon
}

\section{PR Yakoubi Mustapha*}

University Hospital Professor of Orthopedic Surgery, Head of Service, Algiers Faculty of Medicine, Algeria

*Corresponding Author: PR Yakoubi Mustapha, University Hospital Professor of Orthopedic Surgery, Head of Service, Algiers Faculty of Medicine, Algeria.

DOI: 10.31080/ASOR.2020.03.0144

The advent of biotherapies to treat rheumatoid arthritis has profoundly changed the course of the disease. Sometimes it is often aggressive and particularly destructive for the osteo-articular apparatus and soft tissues, especially in the hand.

In rheumatoid arthritis, hand involvement is almost systematic ( $90 \%$ of cases): it can affect all anatomical structures with very variable degrees of severity.

The therapeutic advances of the last 20 years have almost eliminated very advanced forms. But unfortunately this notion does not concern all the so-called developing countries where we always see the forms of historical deformation, especially since the pathology affects young subjects between 35 and 55 years old [1].

In the follow-up of a rheumatoid hand, a surgical opinion should be requested if there is any doubt of a tendon threat or significant joint damage. However, do not wait until the tendon rupture or carpal misalignment is established before taking a surgical opinion, because the proposed intervention will then be much less effective, heavier and a source of residual sequelae. In the analysis of the rheumatoid hand, there is an order of priority which is done from proximal to distal. The wrist is the first joint to analyze and take charge of. This analysis is done in four sectors: the extensors, the distal radio-ulnar (RUD), the radio-carpal, the flexors.

It is in this context that the surgeon intervenes to restore function and provide comfort. The first saving gesture is to make the widest possible synovectomy, thus dismantling the main source in the destructive course of the disease. Technical progress has made it possible to re-orient the wrist and digital channels. MP arthroplasties put these joints in a useful area of mobility. The correction of swan neck deformations must be early. The arthrodesis of
Received: January 24, 2020

Published: February 01, 2020

(C) All rights are reserved by PR Yakoubi

Mustapha the thumb MP is also a winning operation to strengthen the pollidigital forceps. Note that the surgical treatment of severe forms is very complex, and that the functional results are less encouraging. It is through better collaboration between the medical and surgical teams that the operative indications will be brought at the best time.

The management of the rheumatoid hand must be early and multidisciplinary. It requires regular reassessment in order to optimize treatment and avoid disability, a source of disability. The major therapeutic advances of the last 20 years have fortunately made the very debilitating forms much rarer and that the least developed countries must be helped in this direction.

\section{Bibliography}

1. Guillemin F., et al. "Prevalence of rheumatoid arthritis in France: 2001". Annals of the Rheumatic Diseases 64 (2005): 1427-1430.

\section{Assets from publication with us}

- Prompt Acknowledgement after receiving the article

- Thorough Double blinded peer review

- Rapid Publication

- Issue of Publication Certificate

- High visibility of your Published work

Website: https://www.actascientific.com/

Submit Article: https://www.actascientific.com/submission.php Email us: editor@actascientific.com

Contact us: +919182824667 